\title{
ADMINISTRATIVE DEFERENCE AND ITS LINK WITH THE NON-DELEGATION DOCTRINE IN THE LAW OF THE UNITED STATES
}

\author{
Ilaria Di Gioia ${ }^{1}$ \\ Birmingham City University, UK
}

\begin{abstract}
This essay is an exploration of the theoretical origins of administrative deference in the Unites States. It argues that the doctrine of administrative deference finds its theoretical justification in the increasing delegation of the power to execute statutes from Congress to the Executive. It discusses the cases of Chevron and Mead as key cases for the evolution of the delegation doctrine and concludes with the recent treatment of the doctrine in the case of Gundy.
\end{abstract}

Keywords: non, delegation doctrine, administrative deference, Chevron.

Contents: 1 . Introduction. 2. From "non-delegation" to "delegation" doctrine. 3. Chevron and Mead: deference to administrative agencies' interpretation of statutes. 4. No movement (yet) on the non-delegation doctrine: Gundy v. United States (2019).

\section{INTRODUCTION}

The question of whether courts should defer interpretation of ambiguous provisions to agencies is often regarded as a technical question relevant to some aspect of administrative law procedure. In reality, far from being only a technicality, it is a question that encompasses legal issues related to the doctrine of separation of powers and the broader constitutionality of congressional delegation of powers to administrative agencies.

This extended abstract explores the theoretical link between the non-delegation doctrine and the practice of administrative deference. More broadly, it examines the argument that the delegation of power to interpret laws and regulations is an implicit consequence of the delegation of power to execute congressional statutes and issue regulations.

\section{FROM "NON-DELEGATION" TO "DELEGATION" DOCTRINE}

\footnotetext{
${ }^{1}$ Associate Director of the Centre for American Legal Studies, Birmingham City University. Ilaria.DI-GIOIA@bcu.ac.uk
} 
The American Constitution attributes the legislative power to Congress (Art. I), the executive power to the President (Art. II) and the "judicial power" to the courts (Art. III) but it is silent on agency powers. The provisions related to the executive power mainly concern the President and "officers of the United States who are commissioned by the president." 2 Such an omission sits uncomfortably with the recent growth of the administrative state and the consequent increase of the power of agencies that constitute, according to some, a fourth branch of government. ${ }^{3}$ It is a fact that administrative agencies have executive, legislative, and judicial functions. They perform executive functions through agency enforcement, legislative functions through rulemaking and judicial functions through administrative hearings and administrative deference. Even though their role had not been explicitly acknowledged in the text of the Constitution, 4 administrative agencies de facto perform the actions above on delegation of Congress.

Hence, a question is in order: how have the courts justified the delegation of legislative, executive and interpretive power to administrative agencies? The answer is controversial and resides in the modern recognition of the impracticability of a strict application of the traditional non-delegation doctrine. This is the legal doctrine according to which Congress, vested with "all legislative powers" by Article I of the Constitution, cannot delegate these powers to another branch. $^{5}$

With the growth of the administrative state, the courts started to take distance from the traditional understanding of the principle of separation of powers and recognized that overlaps and delegations were necessary for the functioning of the modern state.

\footnotetext{
${ }^{2}$ U.S. CONST. art. II, $\S 3$.

${ }^{3}$ Peter L. Strauss, The Place of Agencies in Government: Separation of Powers and the Fourth Branch, 84 COLUM. L. REV. 573, 576-77 (1984). For an early reflection on the role of agencies see Justice Jackson's dissenting opinion in FederalTrade Commission v. Ruberoid Co., 343 U.S. 470, 487 (1952): "The rise of administrative bodies probably has been the most significant legal trend of the last century and perhaps more values today are affected by their decisions than by those of all the courts, review of administrative decisions apart. They also have begun to have important consequences on personal rights. Cf. United States v. Spector, 343 U.S. 169, 72 S.Ct. 591. They have become a veritable fourth branch of the Government, which has deranged our three-branch legal theories much as the concept of a fourth dimension unsettles our three-dimensional thinking."

${ }^{4}$ David A. Strauss, The Living Constitution (2010) at 122 (stating that "[ $t$ the New Deal is famous for having greatly increased the number of ... agencies" that combined "executive, legislative, and judicial functions").

${ }^{5}$ Notably, the non-delegation doctrine finds deep roots in John Locke's social contract theory: "[t]he power of the legislative, being derived from the people by a positive voluntary grant ..., can be no other than what the positive grant conveyed, which being only to make laws, and not to make legislators". John Locke, Second Treatise on Civil Government $\S \S 141$ (1690). The Supreme Court discussed this principle in numerous instances. See for example Mistretta v. United States, 488 U.S. 361,371 (1989) ("The nondelegation doctrine is rooted in the principle of separation of powers."). See also two early cases: Marshall Field \& Co. v. Clark, 143 U.S. 649, 692 (1892) (That congress cannot delegate legislative power to the president is a principle universally recognized as vital to the integrity and maintenance of the system of government ordained by the constitution.) and Field v. Clark, 143 U.S. 649, 692 (1892).
} 
This essay argues that the result of this development in the jurisprudence and in the law is that the non-delegation doctrine has been weakened to the point of becoming a de facto delegation doctrine that in turn provided the theoretical foundations for the development of the administrative state and -as a consequence- also for the judicial practice of administrative deference, intended here as the delegation of interpretive power to agencies over statutes that they administer or regulations that they issue. The assumption is that if Congress is allowed to delegate lawmaking authority to administrative agencies by providing guidance in the form of intelligible principles, then Congress can also delegate interpretive power over ambiguous statutes administered by the agencies (Chevron deference) or the agencies own regulations (Auer deference). The next section discusses the doctrine of administrative deference as developed by the courts.

\section{ChEVRon ANd Mead: Deference to Administrative AgenCies INTERPRETATION OF STATUTES}

The seminal case concerning administrative deference in the United States is the Chevron case, ${ }^{6}$ a 1984 Supreme Court decision that has become the most cited case in federal administrative law. ${ }^{7}$

In this case the Court suggested that the theoretical basis for administrative deference is the assumption that when Congress delegates implementation to an agency, it also implicitly delegates interpretive authority i.e. the authority to make policy decisions. Justice Stevens delivered the opinion of the Court; he explained judicial deference as a two-steps process; the first step involves an assessment as to whether Congress has already spoken to the precise question at issue. The second step -reached only if Congress did not speak clearly on the issueis to question whether the administrative agency's interpretation is reasonable.

The different extent to which courts should accord Chevron deference was elaborated further by Justice Souter (joined by Rehnquist, C.J., Stevens, O' Connor, Kennedy, Thomas, Ginsburg, and G. Breyer) in United States v. Mead Corp. (2001). ${ }^{8}$

The issue at stake was weather ruling letters issued by the United States Customs Service to classify and fix the rate of duty on imports should be accorded judicial deference.

\footnotetext{
${ }^{6} 467$ U.S. 837 (1984).

${ }^{7}$ See Thomas W. Merrill, Justice Stevens and the Chevron Puzzle, 106 Nw. U. L. REv. 551, 551-53 (2012).

${ }^{8} 533$ U.S. 218 (2001). Mead held that when agencies acted with the "force of law," the Court should accord them Chevron deference.
} 
Justice Souter clarified that Chevron can be applied only to agency regulations that hold the "force of law" i.e. those regulations that have been preceded by the notice and comment as under the Administrative Procedure Act (APA). The ruling letters did not fall under this definition and could only be accorded Skidmore deference.

More importantly, for the purpose of examining the theoretical foundation of deference, is that the decision added a step zero to the two steps devised by Chevron. According to Mead, before proceeding to step one, a court must inquire whether there was congressional intent to delegate to the agency i.e. establish that "Congress delegated authority to the agency generally to make rules carrying the force of law, and that the agency interpretation claiming deference was promulgated in the exercise of that authority." 10

By creating a step 0, Mead formally recognised that when Congress delegates the authority to implement a particular provision, it may also choose to delegate interpretive authority on the same provision. In the words of the then Harvard Professor Elena Kagan, Mead represented "the apotheosis of a developing trend in Chevron cases" that treated Chevron "as a congressional choice, rather than either a constitutional mandate or a judicial doctrine". ${ }^{11}$

Administrative deference is, according to Mead and its progeny, "a judicial construction" 12 or a "fictionalized statement of legislative desire" ${ }^{13}$ that nonetheless reflects the needs of the contemporary administrative state.

If Chevron constituted a pillar of administrative law, the Mead development makes it a constitutional law seminal case with deep roots in theoretical constitutional discourse.

It is not surprising that, for its relevance in the U.S. Constitutional dynamics, it has been at the center of heated debates on the proper allocation of interpretive power and defined by Prof. Sunstein "a kind of counter-Marbury for the administrative state"14 and "the administrative state's very own McCulloch v. Maryland.”15

Mead represents the explanation of the theoretical foundation of administrative deference and this essay argues that its 'step 0 ' is the connecting ring between the nondelegation doctrine and administrative deference.

\footnotetext{
${ }^{9}$ United States v. Mead Corp., 533 U.S. 218, 221 (2001): "We agree that a tariff classification has no claim to judicial deference under Chevron, there being no indication that Congress intended such a ruling to carry the force of law, but we hold that under Skidmore v. Swift \& Co., 323 U.S. 134, 65 S.Ct. 161, 89 L.Ed. 124 (1944), the ruling is eligible to claim respect according to its persuasiveness."

${ }^{10} \mathrm{Id}$. at 226-27.

${ }^{11}$ David J. Barron \& Elena Kagan, Chevron's Nondelegation Doctrine, 2001 SuP. CT. REv. 201, 212 (2001).

${ }^{12} \mathrm{Id}$.

${ }^{13} \mathrm{Id}$.

${ }^{14}$ Cass R. Sunstein, Beyond Marbury: The Executive's Power to Say What the Law Is, 115 YALE L.J. 2580, 2589 (2006).

${ }^{15}$ Cass R. Sunstein, Chevron Step Zero, 92 VA. L. Rev. 187, 190 (2006).
} 
This theoretical assumption has not been free of criticism both from academic circles and court benches. Chevron has been subject to criticism and controversies over what commentators called the 'legal fiction' at the basis of the decision i.e. the presumption that Congress could constitutionally delegate legislative powers to regulatory agencies controlled by the President. ${ }^{16}$

One of the scholarly arguments against Chevron/Mead is that the doctrine is not consistent with Section 706 of the APA which establishes that courts are tasked with the review of agency action and they "shall ... interpret ... statutory provisions." 17 The argument is that the APA does not assign any role in statutory interpretation to agencies ${ }^{18}$ and is therefore to be interpreted as an instruction to courts to use traditional canons of interpretation. ${ }^{19}$

On the constitutional side of the dispute, scholars and judges alike have criticized Chevron/ Mead for incompatibility with Art. I and Art. III.

Justice Thomas expressed discomfort with deference to agencies in Michigan v. EPA (2015), ${ }^{20}$ where he argued that Chevron delegation "is in tension with Article III's Vesting Clause, which vests the judicial power exclusively in Article III courts, not administrative agencies" ${ }^{21}$ and in tension with Art. I "which vests '[a]ll legislative Powers herein granted' in Congress" thus advancing the case for revision of the doctrine.

Another fierce critic of the delegation doctrine and its consequences on administrative deference is Justice Gorsuch who, during his tenure as Appeal Judge, asserted that the doctrine is not only "seemingly at odds with the separation of legislative and executive functions" 22 but also creates concerns related to due process (fair notice) and equal protection that only magistrates "muster." 23

\footnotetext{
${ }^{16}$ The controversy is mainly related to the scope of legislative power of Congress as established by art. 1 of the Constitution. 175 U.S.C. $\$ 706$ (2012): "To the extent necessary to decision and when presented, the reviewing court shall decide all relevant questions of law, interpret constitutional and statutory provisions, and determine the meaning or applicability of the terms of an agency action.".

18 See Patrick J. Smith, Chevron's Conflict with the Administrative Procedure Act, 32 VA. TAx Rev. 813, 818 (2013) (It is impossible to reconcile the requirement in section 706 of the APA that "the reviewing court shall ... interpret ... statutory provisions" with Chevron's holding that, under step two, a reviewing court must accept an agency's "permissible construction of the statute" even if the agency interpretation is not "the reading the court would have reached if the question initially had arisen in a judicial proceeding). See also John F. Duffy, Administrative Common Law in Judicial Review, 77 Tex. L. REv. 113, 193-99 (1988).

${ }^{19}$ Aditya Bamzai, The Origins of Judicial Deference to Executive Interpretation, 126 YALE L.J. 908, 976-95 (2017): “section 706 is best interpreted as an attempt to ... instruct courts to review legal questions using independent judgment and the canons of construction".

${ }^{20}$ Michigan v. E.P.A., 135 S. Ct. 2699 (2015).

${ }^{21} \mathrm{Id}$. at 2712-14.

${ }^{22}$ Gutierrez-Brizuela v. Lynch, 834 F.3d 1142, 1154 (10th Cir. 2016).

${ }^{23} \mathrm{Id}$. at 1152.
} 


\section{No Movement (YET) ON THE NON-DELEgation DoCTRINE: GUNDY V. UNITED STATES (2019)}

In June 2019, the Supreme Court considered a non-delegation challenge and, despite Federalist Society's rumors that the time was ripe for a U-turn on the non-delegation doctrine, ${ }^{24}$ the court confirmed that the post-1935 evolution of the non-delegation doctrine into a delegation doctrine was not to be reversed. The case involved the constitutionality of 34 U.S.C. $\S 20913$ (d), a provision of the Sex Offender Registration and Notification Act (SORNA) that delegates power to the Attorney General "to specify the applicability" of the registration requirements to offenders convicted before the statute's enactment. ${ }^{25}$ The court, in a plurality opinion by Justice Kagan, Ginsburg, Breyer and Sotomayor, held such delegation constitutional. Justice Kagan cited to precedents such as Mistretta ${ }^{26}$ and Hampton ${ }^{27}$ and reiterated that the Constitution allows Congress to delegate discretion as long as Congress provides an intelligible principle to direct the actions of the delegee. She hold that "Congress is on the need to give discretion to executive officials to implement its programs" 28 and therefore argued that delegation is a constitutional necessity that the Court has recognised from a long time. ${ }^{29}$

Justice Alito filed a concurring opinion in which he agreed with Justice Kagan that the post-1935 rejection of non-delegation arguments directed the court to reject this challenge but that he would be open to reconsider this approach if there was a majority. ${ }^{30}$

On the other side of spectrum, Justice Gorsuch filed a 33 pages dissent joined by Chief Justice Roberts and Justice Thomas. His dissenting opinion is, as expected, full of originalist verve. The reader gets the impression that Justice Gorsuch is preparing the ground for a future overhaul of the non-delegation doctrine when he appeals to the intent of the framers to confer

\footnotetext{
${ }^{24}$ See Matthew Cavedon \& Jonathan Skrmetti, Party Like It's 1935?: Gundy v. United States and the Future of the NonDelegation Doctrine, 19 FedERALIST SOC' REV. 42 (2018).

2534 U.S.C.A. $§ 20913$ (D), “The Attorney General shall have the authority to specify the applicability of the requirements of this subchapter to sex offenders convicted before the enactment of this chapter ... and to prescribe rules for the registration of any such sex offenders and for other categories of sex offenders who are unable to comply with subsection (b)."

${ }^{26}$ Mistretta v. United States, 488 U.S. 361 (1989).

${ }^{27}$ J. W. Hampton, Jr., \& Co. v. United States, 276 U.S. 394 (1928).

${ }^{28}$ Gundy v. United States, 139 S. Ct. 2116, 2130 (2019).

${ }^{29} \mathrm{Id}$. ("Consider again this Court's long-time recognition: 'Congress simply cannot do its job absent an ability to delegate power under broad general directives.' Mistretta, 488 U.S. at 372, 109 S.Ct. 647”).

${ }^{30} I d$. at 2131 ("If a majority of this Court were willing to reconsider the approach we have taken for the past 84 years, I would support that effort. But because a majority is not willing to do that, it would be freakish to single out the provision at issue here for special treatment").
} 
sovereignty to the people and insists that delegation of legislative power to the executive frustrates "the system of government ordained by the Constitution." "31

His specific argument is that the delegation of power to specify applicability of the registration requirement constitutes the delegation of unfettered discretion to decide which requirements to impose on which pre-Act offenders and therefore to determine offenders' rights, something that the executive cannot do. ${ }^{32}$

Justice Kavanaugh took no part in the consideration or decision of Gundy because he was not a member of the court when the case was argued in October 2018. However, doubts remain as to what the decision would have been if Kavanaugh had been part of the court and a whether the non-delegation doctrine could stand a future challenge in this conservative-leaning court. Mila Sohoni, commenting on the case on ScotusBlog, rightly contended that "the significance of Gundy lies not in what the Supreme Court did today, but in what the dissent and the concurrence portend for tomorrow." 33

In conclusion, administrative deference remains in the spotlight and its foundations are in peril in the United States. It has resisted a first attack, but this does not provide assurance that it will resist future challenges.

\footnotetext{
${ }^{31} I d$. at 2133 ("The framers understood, too, that it would frustrate "the system of government ordained by the Constitution" if Congress could merely announce vague aspirations and then assign others the responsibility of adopting legislation to realize its goals.19 Through the Constitution, after all, the people had vested the power to prescribe rules limiting their liberties in Congress alone. No one, not even Congress, had the right to alter that arrangement.").

${ }^{32}$ Gundy v. United States, 139 S. Ct. 2116, 2143 (2019).

${ }^{33}$ Mila Sohoni, Opinion analysis: Court refuses to resurrect nondelegation doctrine, ScotusBLOG (June 20, 2019).
} 


\section{LIST OF ABBREVIATIONS}

APA - Administrative Procedure Act

EPA - Environmental Protection Agency

SORNA - Sex Offender Registration and Notification Act

\section{REFERENCE LIST}

34 U.S.C.A. § 20913 (d).

467 U.S. 837 (1984).

5 U.S.C. $§ 706$ (2012).

533 U.S. 218 (2001).

Aditya Bamzai, The Origins of Judicial Deference to Executive Interpretation, 126 YALE L.J. 908-1001 (2017).

Cass R. Sunstein, Beyond Marbury: The Executive's Power to Say What the Law Is, 115 YALE L.J. 2580-2610 (2006).

Cass R. Sunstein, Chevron Step Zero, 92 VA. L. REv. 187-249 (2006).

David A. StRauss, The Living Constitution (2010).

David J. Barron \& Elena Kagan. Chevron's Nondelegation Doctrine, 2001 SuP. CT. REV. 201265 (2001).

Fed. Trade Comm'n v. Ruberoid Co., 343 U.S. 470, 487 (1952).

Field v. Clark, 143 U.S. 649, 692 (1892).

Gundy v. United States, 139 S. Ct. 2116, 2130 (2019).

Gundy v. United States, 139 S. Ct. 2116, 2143 (2019).

Gutierrez-Brizuela v. Lynch, 834 F.3d 1142, 1154 (10th Cir. 2016).

J. W. Hampton, Jr., \& Co. v. United States, 276 U.S. 394(1928).

John F. Duffy, Administrative Common Law in Judicial Review, 77 TEX. L. REV. 113 (1988). John Locke, Second Treatise on Civil Government (1690).

Marshall Field \& Co. v. Clark, 143 U.S. 649, 692 (1892).

Matthew Cavedon \& Jonathan Skrmetti, Party Like It's 1935?: Gundy v. United States and the Future of the Non-Delegation Doctrine, 19 FEDERALIST SoC' REV. $42-53$ (2018).

Michigan v. E.P.A., 135 S. Ct. 2699, (2015).

Mila Sohoni, Opinion analysis: Court Refuses To Resurrect Nondelegation doctrine, SCOTUSBLOG (June 20, 2019), https://www.scotusblog.com/2019/06/opinion-analysis-courtrefuses-to-resurrect-nondelegation-doctrine/

Mistretta v. United States, 488 U.S. 361 (1989). 
Patrick J. Smith, Chevron's Conflict with the Administrative Procedure Act, 32 VA. TAX REV. 813-40 (2013).

Peter L. Strauss, The Place of Agencies in Government: Separation of Powers and the Fourth Branch, 84 CoLum. L. REV. 573-669 (1984).

Skidmore v. Swift \& Co., 323 U.S. 134, 65 S.Ct. 161, 89 L.Ed. 124 (1944).

Thomas W. Merrill, Justice Stevens and the Chevron Puzzle, 106 Nw. U. L. REV. 551-66 (2012).

U.S. CONST.

United States v. Mead Corp., 533 U.S. 218, 221 (2001).

United States v. Spector, 343 U.S. 169, 72 S.Ct. 591. 